ISSN: 1907-9931 (print), 2476-9991 (online)

\title{
VARIATIONS OF INDONESIAN THROUGHFLOW TRANSPORT IN MALUKU AND HALMAHERA SEA RELATED TO THE OCCURRENCE OF EL NINO SOUTHERN OSCILLATION
}

\author{
Hasti Amrih Rejeki ${ }^{*}$, Betsi ${ }^{2}$, Yogi Muhammad Andariwan ${ }^{3}$ \\ ${ }^{1}$ Department of Meteorology, Indonesian School of Meteorology Climatology and Geophysics, \\ Tangerang Selatan, Indonesia \\ ${ }^{2}$ Sultan Iskandar Muda Meteorological Station, Indonesian Agency for Meteorology Climatology and \\ Geophysics, Banda Aceh, Indonesia \\ ${ }^{3}$ Sam Ratulangi Meteorological Station, Indonesian Agency for Meteorology Climatology and \\ Geophysics, Manado, Indonesia \\ "Corresponding author e-mail: hastiamrihrejeki@stmkg.ac.id
}

Submitted: 30 September 2021 / Revised: 24 November 2021 / Accepted: 24 December 2021

http://doi.org/10.21107/jk.v14i3.12083

\begin{abstract}
Maluku and Halmahera Sea are the entry paths for the Indonesian Throughflow (ITF). This study examined the variation of their current speed, current direction, and transport during the ENSO phases on La Nina in 2010-2011 and El Nino in 2015-2016. The data used were the Marine Copernicus reanalysis data of $u$ and $v$ components of current velocity at $155 \mathrm{~m}$ and $266 \mathrm{~m}$ of depth. The data were processed by using GrADS to see the direction and speed of the current as well as by calculating the ITF transport. During La Nina, both at $155 \mathrm{~m}$ and $266 \mathrm{~m}$ of depths were found the eddy patterns. When El Nino occurred, the direction of currents in Maluku Sea was different from La Nina conditions, while the direction of currents in Halmahera Sea had no differences. Current velocity in both oceans at each depth was lower during El Nino than La Nina. The condition of ITF transport in the Maluku Sea during La Nina was dominated by southward movement with a smaller value than during El Nino which generally moved northward meanwhile in the Halmahera Sea had the opposite condition.
\end{abstract}

Keywords: current speed, current direction, ENSO, ITF, transport

\section{INTRODUCTION}

Along the year there is a mass exchange of seawater between the Pacific Ocean and the Indian Ocean that passes through the Indonesian waters (Luick, 2001). In the normal condition, the southeast trade winds blow in the Ocean, pushing the Pacific water mass toward the west which, causing a buildup of water mass in the western Pacific near Indonesia, so the sea level between the western Pacific Ocean and the Indian Ocean which is located in the south of Indonesia is different (Hasanudin, 1998). This height difference will cause different pressure gradients between the western Pacific Ocean and the eastern Indian Ocean, with a strong gradient concentrated at a depth of 250 $\mathrm{m}$ (Wyrtki, 1987), resulting in a mass flow of seawater from the Pacific Ocean to the Indian Ocean. This mass flow of seawater is referred to as the Indonesian Through Flow (ITF) (Sudjono et al., 2004).

The ITF conveys through the Indonesian waters through two routes. The first is the western route, it flows above the thermocline layer carrying the North Pacific Subtropical Water (NPSW) and North Pacific Intermediate Water (NPIW) through the Sulawesi Sea and then into the Makassar Strait, then this water mass goes to the Indian Ocean through the Lombok Strait, but there is a mass of water that reaches the Flores Sea and Banda Sea first before finally exiting into the Indian Ocean through the Ombai Strait and the Timor Pass (Gordon \& Fine, 1996; Arief \& Murray, 1996; and Wattimena et al., 2018 ). The second is the eastern route, which carries the South Pacific Intermediate Water (SPIW) into the Maluku Sea, the Lifamatola Strait and the Banda Sea to the Indian Ocean through the Ombai Strait and the Timor Pass; the ITF also enters through the Halmahera Sea carrying the South Pacific Subtropical Water (SPSW) to the Seram Sea and mixed in the Banda Sea together with ITF entering through the Maluku Sea (Tranchant et al., 2016). 
Jurnal Kelautan, 14(3), 243-253 (2021)

Both of the east and west routes of ITF have different transport volumes, but the dynamics of the ocean and atmosphere in the Indo-Pacific region causes the ITF to experience variability over a wide range of timescale, such as the El Nino Southern Oscillation (ENSO) phenomenon which is an ocean-atmosphere interaction in the Pacific Ocean on an interannual time scale (Atmadipoera et al., 2016) which can cause ITF transport volumes to fluctuate, i.e., the ITF transport weakens during El Nino and strengthens during La Nina (Meyers, 1996; Fieux et al., 1996; and Gordon et al., 2008). ITF entering through the Sulawesi Sea has a maximum speed of $150-250 \mathrm{~m}$ depth, below this layer the current velocity decreases with increasing depth (Atmadipoera \& Mubaraq, 2016).

According to Yuan et al. (2018), it is explained that many studies on ITF transport focus on the western route, such as the research in the Makassar Strait area conducted by Gordon et al. (1999), (2008) and Susanto \& Gordon (2005), research in the Lombok Strait, Ombai Strait, and the Timor Passage as the ITF exit route to the Indian Ocean carried out by Murray and Arief (1988), Arief \& Murray (1996), Cresswell et al. (1993), Molcard et al. (1994), (1996), (2001), and Sprintall et al. (2009). In connection with the occurrence of La Nina with a strong intensity in 2010 and El Nino with a very strong intensity in 2015 (Atmadipoera et al., 2020) as well as the presence of many studies on the ITF western route, the aim of this study was to examine the variations in the direction and speed of currents and ITF transport when La Nina was active for the 20102011 period and El Nino for the 2015-2016 period on the eastern route of the ITF based on data model, that is in the Maluku Sea and the Halmahera Sea.

\section{MATERIALS AND METHODS}

This study took place in the eastern route of the ITF entry, namely the Maluku Sea and the Halmahera Sea (Wattimena et al., 2018). The depth level reviewed in this study is at a depth of about $150 \mathrm{~m}$ and $250 \mathrm{~m}$ because the vertical structure of the current reveals that the Arlindo flow has intensified at depths between $150 \mathrm{~m}$ and $250 \mathrm{~m}$ (Atmadipoera \& Mubaraq, 2016). The Maluku Sea is located between the islands of Sulawesi and North Maluku, but this study focused on the coordinates of $1.6^{\circ} \mathrm{N}$ and $125.3^{\circ} \mathrm{E}-127.4^{\circ} \mathrm{E}$. Meanwhile, the Halmahera Sea is located between the Halmahera Island, Waigeo, North Maluku, and Irian Jaya, but this study focused on the coordinates of $0.1^{\circ} \mathrm{N}$ and $128.8^{\circ} \mathrm{E}-130.2^{\circ} \mathrm{E}$ as shown in Figure 1.

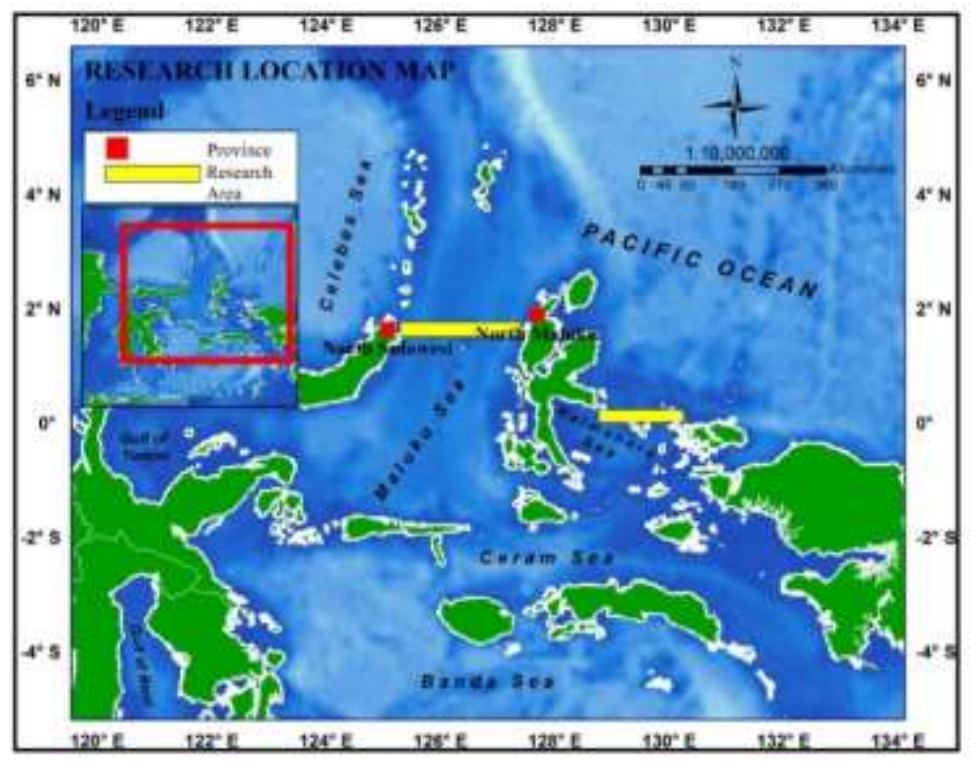

Figure 1. Research location

This study focused on the ENSO event during La Nina in 2010-2011 with a weak to strong intensity and EI Nino in 2015-2016 with a weak to very strong intensity (Atmadipoera et al., 2020). To identify the intensity of ENSO, this study used Oceanic Nino Index (ONI) data during June 2010 - June 2011 and June 2015
- June 2016 which the data were the average sea surface temperature in 3 months in the Nino 3.4 region obtained from Ggweather that positive ONI indicates EI Nino and negative ONI indicates La Nina (Ggweather, 2019). Furthermore, ENSO conditions are categorized based on their intensity as follows: 
Rejeki et al., Variations Of Indonesian Throughtflow Transport

\begin{tabular}{cc}
\hline Table 1. ENSO intensity prediction guide based on Oceanic Nino Index (ONI) values \\
\hline ONI Value & ENSO Intensity \\
\hline $0.5-0.9$ & Weak \\
$1.0-1.4$ & Moderate \\
$1.5-1.9$ & Strong \\
$\geq 2.0$ & Very strong \\
\hline
\end{tabular}

Source: (Ggweather, 2019)

The data used in this study included daily and monthly Global Ocean Physics Reanalysis data obtained from Copernicus Marine in netCDF format with a resolution of $0.083^{\circ} \times 0.083^{\circ}$ in the form of current velocity parameters of components $u$ and $v$ at a depth of 155 and 266 $\mathrm{m}$ which are adjusted to the depth of intensive ITF identification at a depth of $150 \mathrm{~m}$ and 250 $\mathrm{m}$ (Atmadipoera \& Mubaraq, 2016).

The calculation of the cross-sectional area of the Maluku Sea and the Halmahera Sea at a depth of $155-266 \mathrm{~m}$ was $25,949,136 \mathrm{~m}^{2}$ for the Maluku Sea and $17,299,461 \mathrm{~m}^{2}$ for the Halmahera Sea. Then the ITF transport volume was calculated using the GrADS application by entering the value of current velocity $v$ and the value of the cross-sectional area into equation 1 (Nanlohy et al., 2018) as follows:

$S=V \times d A$

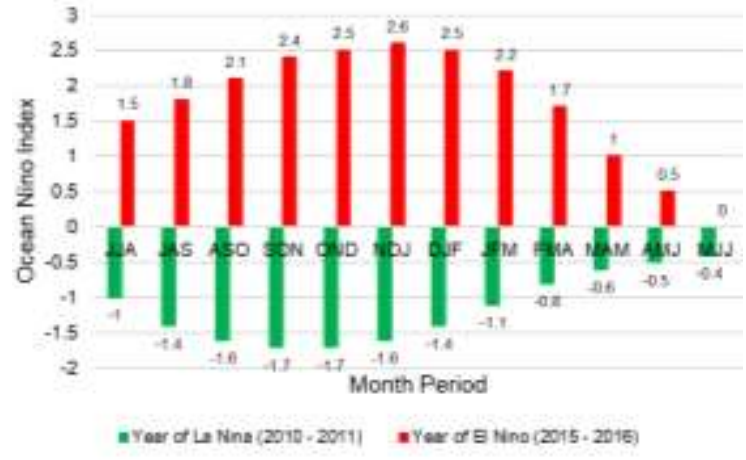

Figure 2. Oceanic Nino Index during La Nina 2010-2011 and El Nino 2015-2016

\section{Current speed and direction in Maluku Sea and Halmahera Sea in La Nina 2010-2011 period.}

Based on Figure 3a, the ITF in the Maluku Sea in July 2010 moved from the western Pacific Ocean near the Philippines to the south towards the western part of the Maluku Sea with a dominant speed of $0.15-0.4 \mathrm{~m} / \mathrm{s}$. In August (Figure $3 \mathbf{b}$ ) to November (Figure 3e), the speed increased to $0.40-0.65 \mathrm{~m} / \mathrm{s}$. In December (Figure 3f), the ITF speed deceased to 0.15$0.4 \mathrm{~m} / \mathrm{s}$. In January (Figure $\mathbf{3 g}$ ) to February 2011 (Figure 3h), the current weakened and its speed slowed down to $0.1-0.3 \mathrm{~m} / \mathrm{s}$. In March (Figure 3i), the current speed weakened to less than $0.15 \mathrm{~m} / \mathrm{s}$. In April (Figure 3j), in most of the study areas no significant currents were

\section{Where: \\ S : ITF transport volume ( $\mathrm{m}^{3} / \mathrm{s}$ or $\left.\mathrm{Sv}\right)$ \\ $\mathrm{V} \quad$ : The average of current speed of $\mathrm{v}$ component $(\mathrm{m} / \mathrm{s})$ at the depth of $155 \mathrm{~m}$ \\ dA : Cross-sectional area $\left(\mathrm{m}^{2}\right)$ \\ Result Identifying ENSO Intensity}

Based on the value of the Oceanic Nino Index (ONI) in July 2010 - July 2011 and July 2015 July 2016, it can be seen that El Nino and La Nina events in that period varied from weak to strong intensity (Figure 2). In the period June, July, and August (JJA) 2010 to March, April, May (MAM) 2011 La Nina is active while in the period June, July, and August (JJA) 2015 until March, April, May (MAM) 2016 El Nino active. observed. The ITF current pattern was only found at the southern end of the study area with a speed of less than $0.25 \mathrm{~m} / \mathrm{s}$. In May 2011 (Figure 3k), the ITF started moving again and the current velocity in the study area ranged from $0.1-0.45 \mathrm{~m} / \mathrm{s}$.

From August 2010 (Figure 3b) to January 2011 (Figure 3g) there were eddy patterns at a depth of $155 \mathrm{~m}$ in the Maluku Sea. It can be seen that the eddy patterns started to form in August 2010 (Figure 3b), experienced an increased speed in September 2010 (Figure 3c), and decreased in speed in December 2010 (Figure 3f). The eddy patterns formed were found in 2 locations, such as in the north and south of the Maluku Sea, both of which were counterclockwise eddies. 
ITF in the Halmahera Sea, in July 2010 (Figure 3a) had speed ranging from $0.1-0.4 \mathrm{~m} / \mathrm{s}$. In August (Figure 3b) and September (Figure 3c), the velocity became less than $0.2 \mathrm{~m} / \mathrm{s}$. In October (Figure 3d) and November (Figure 3e), the ITF weakened at a rate of less than 0.2 $\mathrm{m} / \mathrm{s}$, with a distribution in the southern part of the study area. In December 2010 (Figure 3f) and
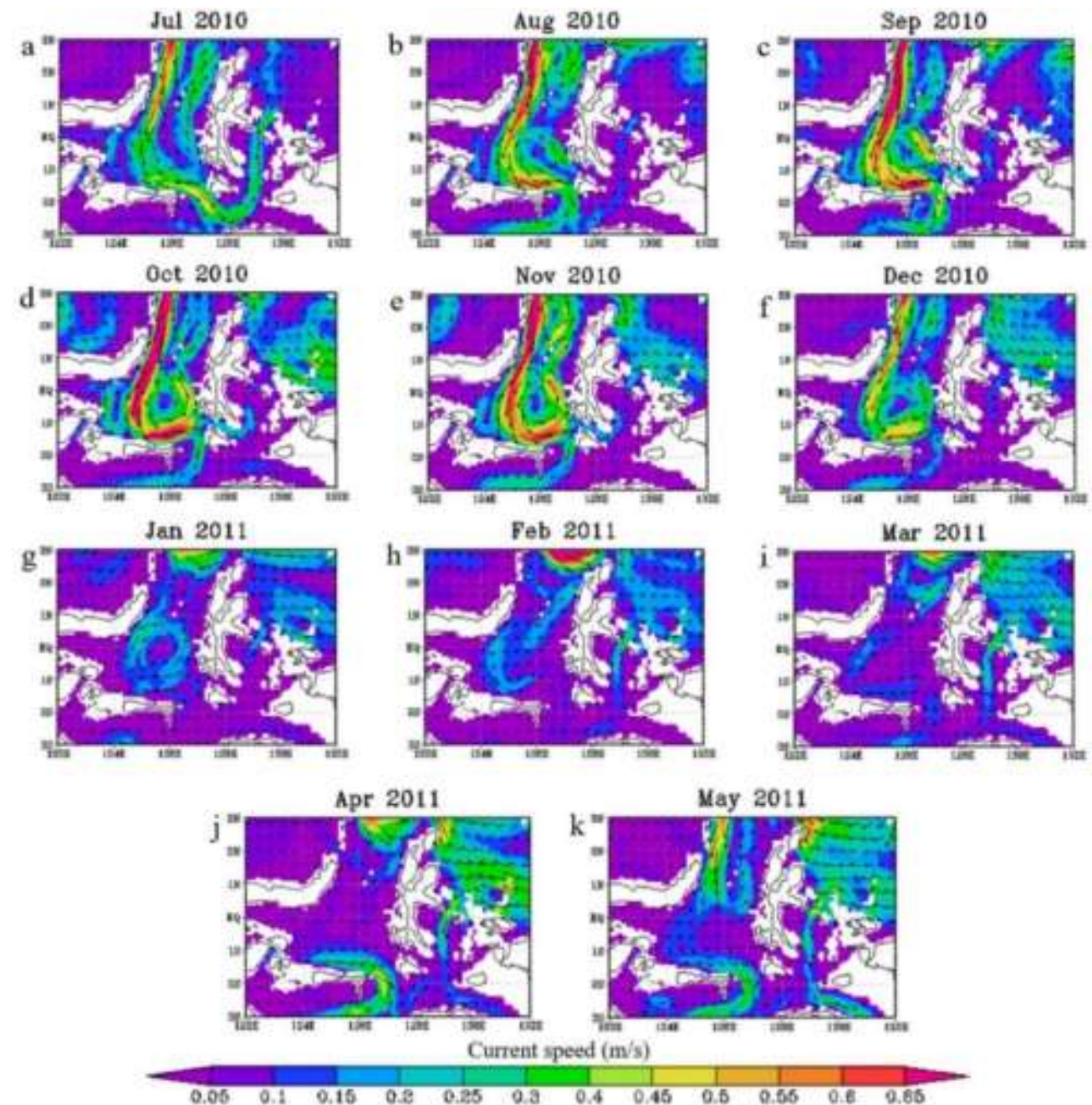

Figure 3. Current speed and direction at a depth of $155 \mathrm{~m}$ in La Nina period, a) July 2010; b) August 2010; c) September 2010; d) October 2010; e) November 2010; f) December 2010; g) January 2011;

h) February 2011; i) March 2011; j) April 2011; k) May 2011

Figure 4 shows the pattern of current direction and speed which is a visualization of the movement and speed of the ITF in the Maluku Sea and Halmahera Sea at a depth of $266 \mathrm{~m}$ from July 2010 to May 2011. In terms of the current direction pattern at a depth of $266 \mathrm{~m}$, there were similarities with the ITF movement pattern at a depth of 155 meter where the current in the Maluku Sea moved southward and an eddy pattern was found in February 2016 (Figure 4h) while the current in the Halmahera Sea moved from the north to the south and some went the east.

The ITF velocity in the Maluku Sea in July 2010
(Figure 4a) ranged from $0.1-0.3 \mathrm{~m} / \mathrm{s}$. In August (Figure 4b) and September (Figure 4c), the ITF speed decreased to less than 0.2 $\mathrm{m} / \mathrm{s}$ and the distribution was only in the southern part of the study area. From October 2010 (Figure 4d) to January 2011 (Figure 4g), the ITF speed ranged from $0.1-0.3 \mathrm{~m} / \mathrm{s}$. After that, in February (Figure 4h) and March (Figure 4i) the ITF speed reduced to less than $0.2 \mathrm{~m} / \mathrm{s}$. Then in April (Figure 4j) and May 2011 (Figure 4k) the ITF speed increased again to between $0.1-0.45 \mathrm{~m} / \mathrm{s}$. Meanwhile, the ITF speed in the Halmahera Sea in July and August 2010 was not significant, which was less than $0.05 \mathrm{~m} / \mathrm{s}$. The ITF speed increased in 
Rejeki et al., Variations Of Indonesian Throughtflow Transport

September 2010 to less than $0.2 \mathrm{~m} / \mathrm{s}$. On the other hand, the ITF speed was not significant until April 2011. In May 2011, there was a slight increase in the speed in the southern part of the study area to less than $0.15 \mathrm{~m} / \mathrm{s}$.

At a depth of $266 \mathrm{~m}$, eddy patterns were also be found, but not as many as those at a depth of
$155 \mathrm{~m}$. The eddy pattern started to be seen in the North Maluku Sea in December 2010 (Figure 4f). Furthermore, the eddy pattern was seen in January 2011 (Figure $\mathbf{4 g}$ ) but was only visible in the southern part of the Maluku Sea and started to disappear in March 2011 (Figure 4i). The eddy was seen at a depth of $266 \mathrm{~m}$ had an counterclockwise pattern.
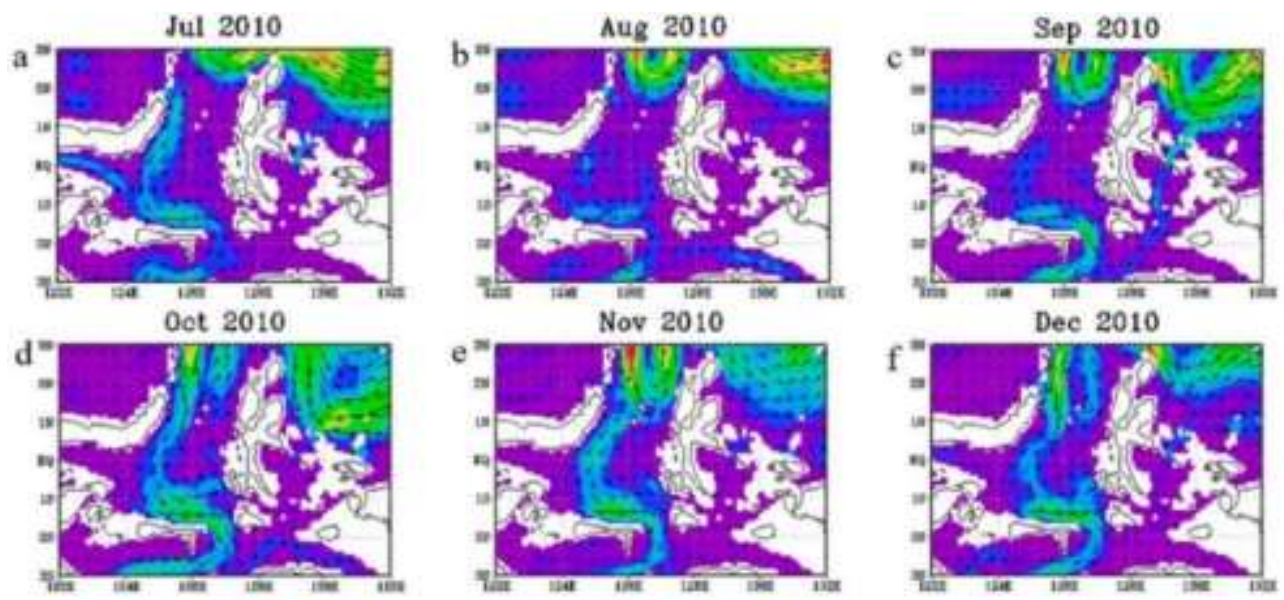

$\operatorname{Jan} 2011$
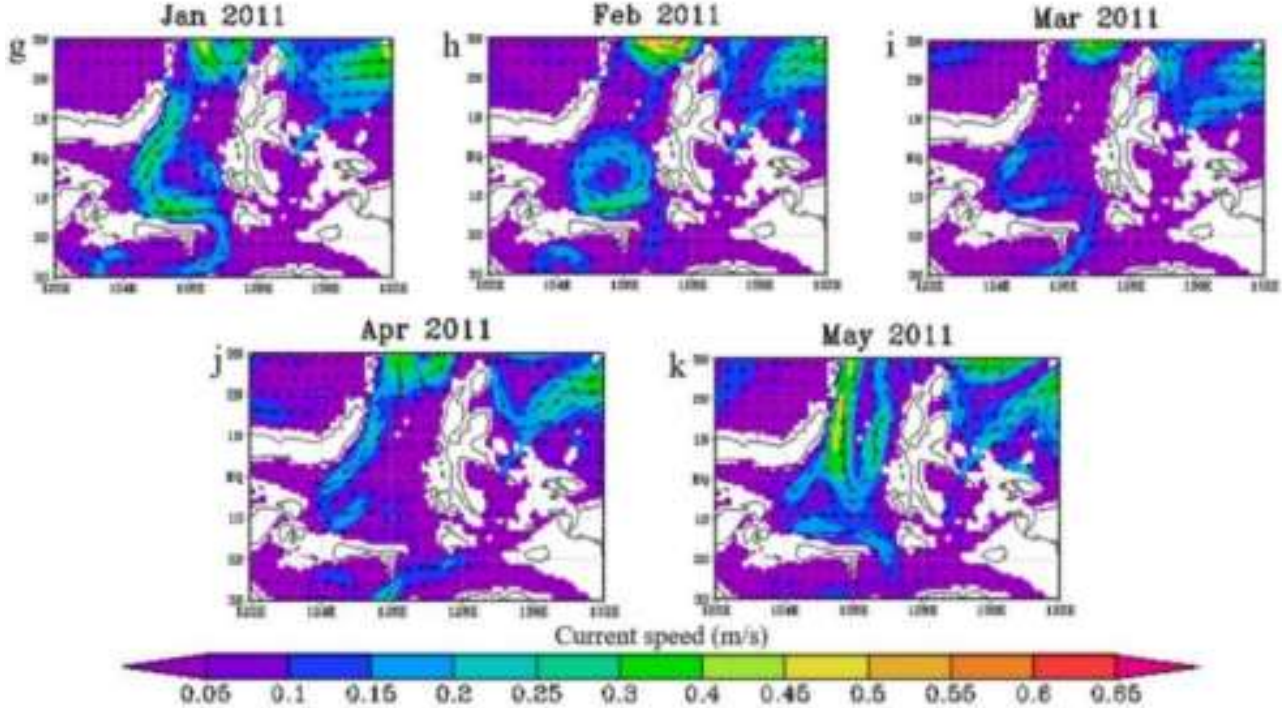

Figure 4. Current speed and direction at a depth of $266 \mathrm{~m}$ in La Nina period, a) July 2010; b) August 2010; c) September 2010; d) October 2010; e) November 2010; f) December 2010; g) January 2011; h) February 2011; i) March 2011; j) April 2011; k) May 2011

\section{Current speed and direction in Maluku Sea and Halmahera Sea in EI Nino 2010-2011 period}

In general, the movement of ITF in the study area had a different pattern when compared to the movement in strong La Nina condition in July 2010 to May 2011. When the El Nino occurred in July 2015 (Figure 5a) to May 2016 (Figure 5k), the general pattern of the ITF movement in the Maluku Sea was from the north to the southeast. After it meet the northwestern part of Halmahera Island, the ITF was deflected to the south and moved to the southwest. As a consequence, the ITF was divided into two, namely moving west and entering the Tomini Bay and turning east and passing the Lifamatola Chanel. This movement caused a significant ITF speed $(>0.05 \mathrm{~m} / \mathrm{s})$ in the Maluku Sea, mostly concentrated in the southern part. Meanwhile, for the Halmahera Sea, the ITF movement patterns tended to change. In September 2015 (Figure 5c) to December 2015 (Figure 5f), the ITF moved from the Maluku Sea to the Banda Islands and then into the Halmahera Sea and finally exited through the Jailolo Strait. 

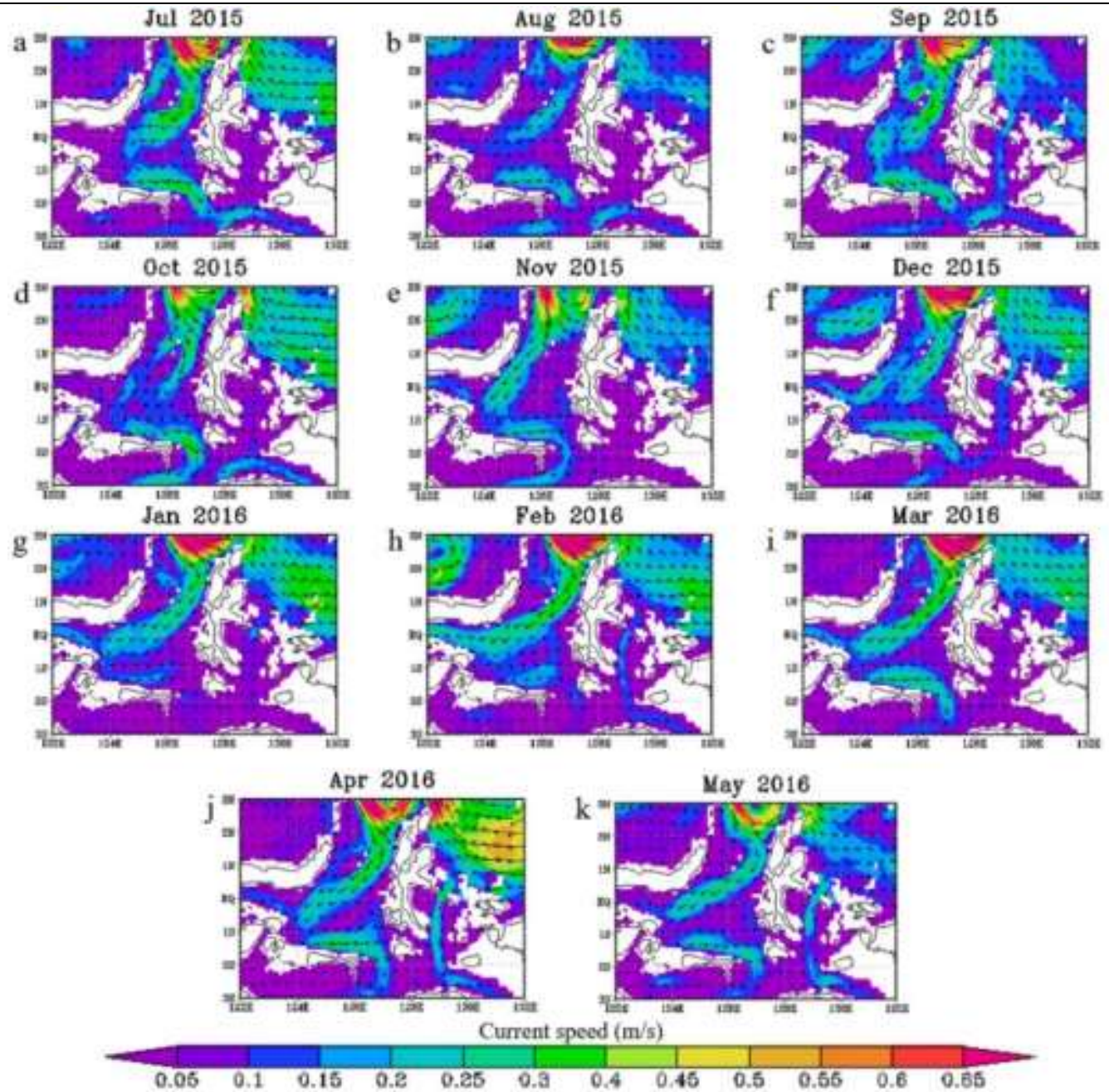

Figure 5. Current speed and direction at a depth of $155 \mathrm{~m}$ in El Nino, a) July 2015; b) August 2015; c) September 2015; d) October 2015; e) November 2015; f) December 2015; g) January 2016; h)

February 2016; i) March 2016; j) April 2016; k) May 2016

In the Maluku Sea, in July 2015 the ITF speed ranged from $0.1-0.3 \mathrm{~m} / \mathrm{s}$. In August the speed reduced to less than $0.25 \mathrm{~m} / \mathrm{s}$. In September, the current conditions were similar to the July condition. The ITF speed condition in October reduced to less than $0.2 \mathrm{~m} / \mathrm{s}$. In November, there was a different movement pattern compared to other months, namely from the north along the western part of the Maluku Sea then when it met the Sula Islands it was deflected to the east and finally exited through the Lifamatola Chanel. The ITF speed ranged from 0.05-0.3 m/s. In December, the ITF with a significant speed spread almost evenly throughout the Maluku Sea, and in the study area the velocity ranged from $0.1-0.25 \mathrm{~m} / \mathrm{s}$. Furthermore, from January 2016 to May 2016, the ITF movement pattern had similarities with the ITF speed, varying between 0.05-0.3 m/s. For the Halmahera Sea, the ITF with a significant speed began to be seen in September 2015, namely at a speed between $0.1-0.2 \mathrm{~m} / \mathrm{s}$. Subsequently in October, the velocity reduced to less than $0.5 \mathrm{~m} / \mathrm{s}$ and in November there was no significant ITF velocity. In December, the ITF speed started to increase to $0.1-0.2 \mathrm{~m} / \mathrm{s}$. In January 2016 , the speed was the same but only in the northern part of the study area. In February, the ITF speed increased and became the same as that in December. In March the ITF speed decreased and had no significant speed. Subsequently in April and May, the ITF speed increased to within the range of $0.15-0.3 \mathrm{~m} / \mathrm{s}$. 

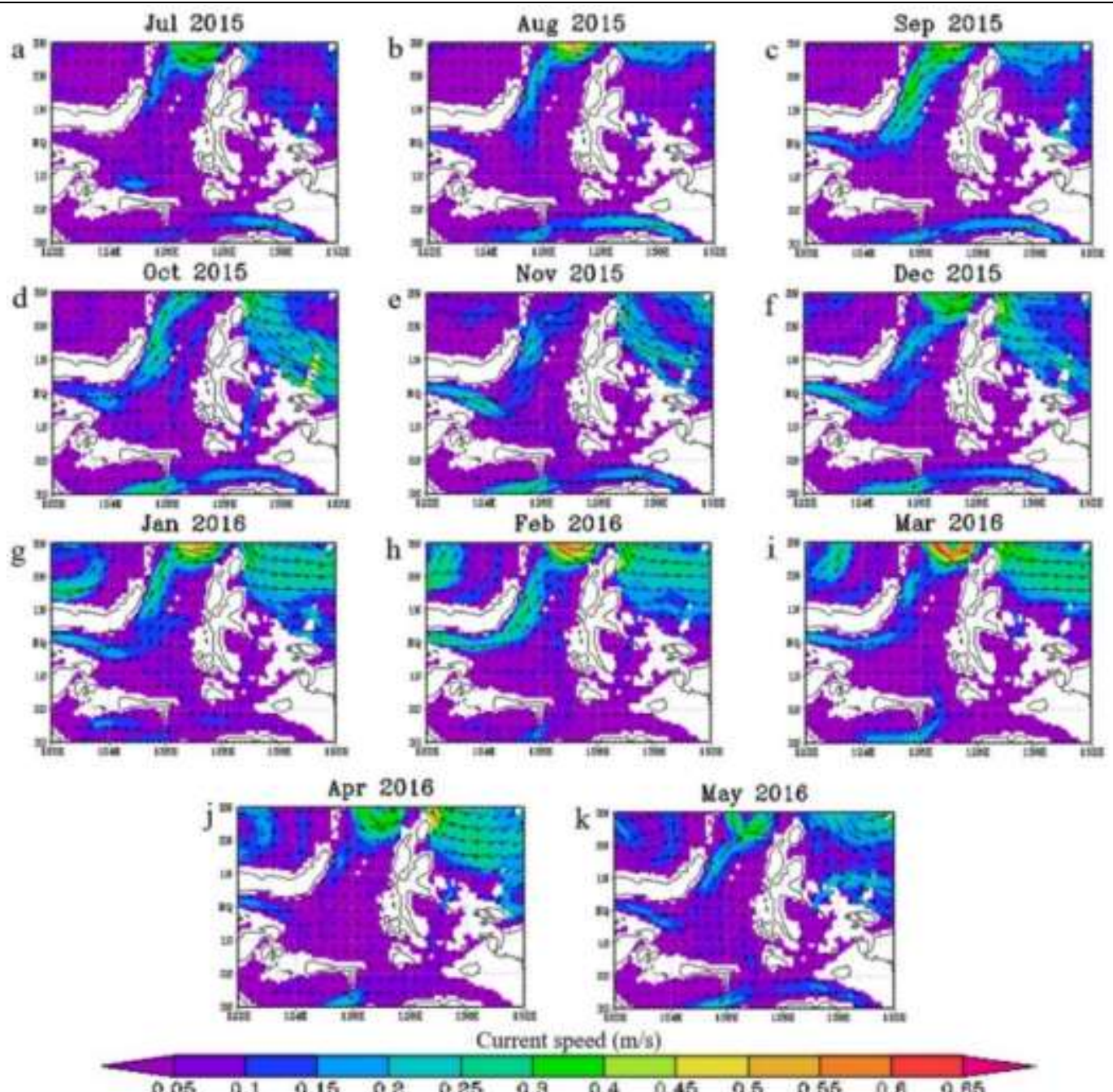

Figure 6. Current speed and direction at a depth of $266 \mathrm{~m}$ in El Nino period, a) July 2015; b) August 2015; c) September 2015; d) October 2015; e) November 2015; f) December 2015; g) January 2016; h) February 2016; i) March 2016; j) April 2016; k) May 2016

It should be noted that the ITF movement at a depth of 266 meter had a different pattern when compared to the ITF movement at a depth of 155 meter. This condition was different from the ITF movement when La Nina occurred in July 2010 (Figure 3a) to May 2011 (Figure 3k). In general, the ITF in the Maluku Sea moved out of the Tomini Bay to the northeast along the plains of the northern part of the Sulawesi Island and towards the northern part of the Maluku Sea, while at the depth of $155 \mathrm{~m}$ the current movement was into Tomini Bay. In Halmahera Sea, the ITF movement at the depth of $266 \mathrm{~m}$ was still the same as the movement at a depth of 155 meter.

As its movement, a significant ITF speed in the Maluku Sea was found in the northern part of the study area. In July and August 2015 (Figures $6 a$ and $6 b$ ), the ITF speed was less than $0.2 \mathrm{~m} / \mathrm{s}$. In September and October 2015 (Figures $\mathbf{6 c}$ and $6 \mathrm{~d}$ ) the speed increased to less than $0.3 \mathrm{~m} / \mathrm{s}$. In November and December 2015 (Figures 6e and 6f), the speed decreased to less than $0.25 \mathrm{~m} / \mathrm{s}$. In January and February 2016 (Figures $\mathbf{6 g}$ and $6 \mathbf{6 h}$ ), the ITF speed increased to less than $0.3 \mathrm{~m} / \mathrm{s}$. Then in March (Figure 6i) to May 2016 (Figure 6k), the speed decreased to less than $0.2 \mathrm{~m} / \mathrm{s}$. During El Nino, eddy patterns were found neither at a depth of $155 \mathrm{~m}$ nor at a depth of 266 depth.

\section{Monthly ITF transport in Maluku Sea}

Based on the results of the calculation of the average transport in Figure $7 a$, it can be seen that the average monthly ITF transport in the Maluku Sea during weak La Nina ranged from $(-0.06)-(-1.45)$ Sv. The negative sign (-) indicated that the ITF flowed southward (Wattimena et al., 2018). When moderate La Nina occurred, it ranged from $(-0.32)-(-1.86)$ Sv and when strong La Nina occurred, it ranged from $0.38-(-1.04) \mathrm{Sv}$. Figure $\mathbf{7 b}$ shows that 
Jurnal Kelautan, 14(3), 243-253 (2021)

the average monthly transport in the Maluku Sea during El Nino at a weak intensity was 2.63 $\mathrm{Sv}$, at a moderate intensity was $0.99 \mathrm{~Sv}$, at a

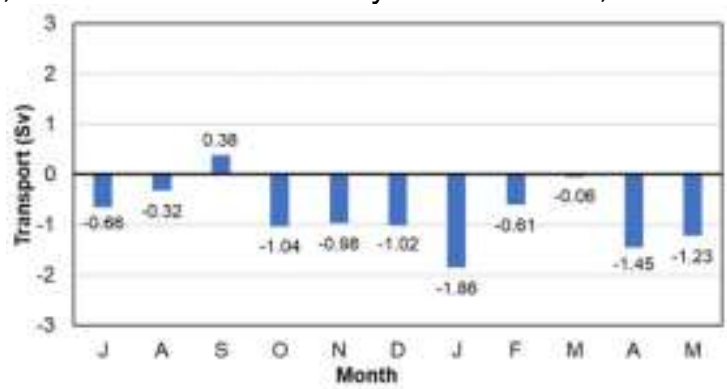

(a) strong intensity was $0.99-1.7 \mathrm{~Sv}$, while at a very high intensity it ranged from $1.43-2.4 \mathrm{~Sv}$.

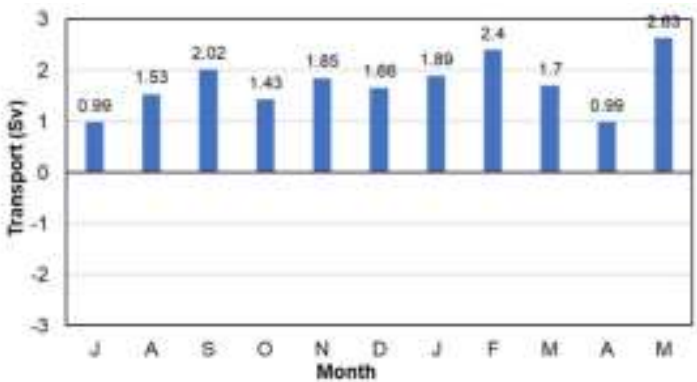

(b)

Figure 7. Monthly ITF Transport in the Maluku Sea in (a) La Nina 2010 - 2011 period and (b) El Nino $2015-2016$ period

The results of the annual average calculation shown in Table 2 show that the average condition of the ITF transport during the La Nina period was lower than during the El Nino period.
During La Nina, the ITF transport was $-0.81 \mathrm{~Sv}$ to the south direction, while during El Nino the ITF transport was $1.54 \mathrm{~Sv}$ northward.

Table 2. Annual average ITF transport in the Maluku Sea in La Nina $2010-2011$ period and EI Nino $2015-2016$ period

\begin{tabular}{cc}
\hline Period & Annual average transport \\
\hline La Nina 2010-2011 & $-0.81 \mathrm{~Sv}$ \\
\hline El Nino 2015-2016 & $1.54 \mathrm{~Sv}$ \\
\hline
\end{tabular}

\section{Monthly ITF transport in Halmahera Sea}

Based on the calculation of the average transport in Figure 8a, it can be seen that the average monthly ITF transport in the Halmahera Sea during La Nina with a weak intensity ranged from 0.47 to $1.28 \mathrm{~Sv}$. At a moderate intensity, it ranged from 0.62 to 1.46 Sv, while at a strong intensity it ranged from 0.95 to $1.65 \mathrm{~Sv}$. Figure $\mathbf{8 b}$ shows that the average monthly transport in the Maluku Sea during El Nino at a weak intensity was $1,11 \mathrm{~Sv}$, at a moderate intensity was $-1,06 \mathrm{~Sv}$, at a

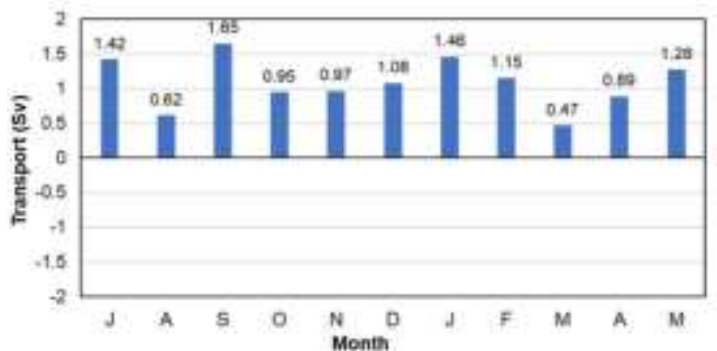

(a) strong intensity was $0,48-(-0,98) \mathrm{Sv}$, and at a very strong intensity it ranged from $(-0.51)-(-$ 1.29) Sv.

Table 3 shows that the annual average ITF transport in the Halmahera Sea during the La Nina and El Nino events had a higher value than the ten-year average. The average ITF transport during the La Nina period was higher than that during the El Nino period, i.e., 1,09 Sv northward during $\mathrm{La}$ Nina and $-0.5 \mathrm{~Sv}$ southward during El Nino.

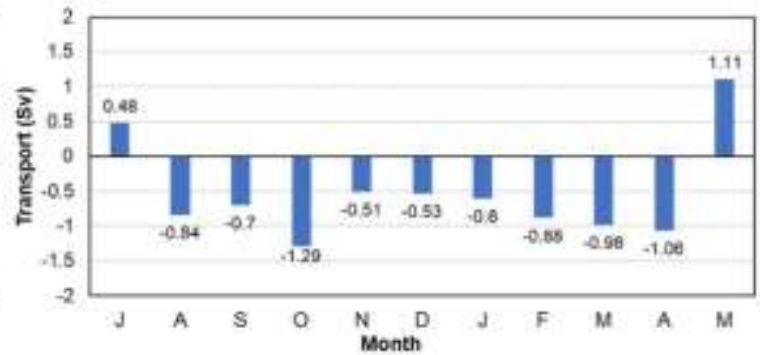

(b)

Figure 8. The ITF transport in the Halmahera Sea in (a) La Nina $2010-2011$ period and (b) El Nino $2015-2016$ period

Table 3. Annual average ITF transport in the Halmahera Sea in La Nina $2010-2011$ period and El Nino $2015-2016$ period

\section{Period}

La Nina 2010-2011

El Nino 2015-2016
Annual average transport

$1.09 \mathrm{~Sv}$

-0 . Sv 
Rejeki et al., Variations Of Indonesian Throughtflow Transport

Discussion

Based on the pattern of the current direction and speed in Figure 3, it can be seen that the ITF moved from the northern part of the Maluku Sea because during El Nino, the ITF in the Maluku Sea originated from North Equatorial Current (NEC) system then bifurcated to be Mindanao Current (MC) and Kuroshio Current (KC). MC advected to Sulawesi, Maluku, and become North Equatorial Counter Current (NECC) (Wang et al., 2019). The ITF turned east which was then divided into two directions. First, to the north and then returned to the northern part of the Maluku Sea, second, the ITF entered the Lifamatola Chanel and the Banda Sea. In the first pattern, the ITF movement that returned to the north caused an eddy in August 2010 (Figure 3b) to January 2011 (Figure 3g).

In terms of the movement patterns in the Halmahera Sea, starting from July 2010 to November 2010, the ITF in the Halmahera Sea originated from the ITF from the Maluku Sea that entered through the Obi Strait. This condition is different when compared to a study by Wattimena et al., (2018), showing that the ITF in the Halmahera Sea throughout the year tends to move from the north to south. Then from December 2010 to May 2011, the ITF moved from the Pacific Ocean through the Jailolo Strait and out to the south to the Banda Sea. This movement was triggered by the New Guinea Coastal Current which moved from the coast of Papua to the west (Wattimena, et al., 2018). During El Nino, the ITF in the Halmahera Sea was a mix of currents originating from the northern and southern Pacific Oceans (Wang et al., 2019).

In general, the ITF speed at a depth of $266 \mathrm{~m}$ was lower than that at a depth of $155 \mathrm{~m}$. These results are in accordance with a study conducted by Atmadipoera and Mubaraq (2016). There were also different current directions between El Nino and La Nina, especially at $266 \mathrm{~m}$. The current direction during La Nina moved from the north, but then it changed to the direction from the south. It is seen that the current began to be in a reverse direction, namely from the Pacific Ocean entering through the Jailolo Strait, from January 2016 to May 2016.

The fact that eddy patterns were found in the north and south of the Maluku Sea, at a depth of $155 \mathrm{~m}$ is similar with research by Wang et al., (2019) in which this study also found the presence of eddies at subsurface depths in the north and south of the Maluku Sea. However, in the research of Wang et al., (2019), the eddy in the north of the Halmahera Sea had a cyclonic pattern and that in the south had a counterclockwise pattern. Meanwhile in this study, both the eddies in the north and south had a counterclockwise pattern. In addition, it is suspected that due to a decrease in the current speed during El Nino, eddy patterns were not found in the Maluku Sea during that period.

The monthly average condition of the ITF transport in the Maluku Sea when La Nina (Figure 7a) reached its maximum in January 2011 (moderate La Nina) of $-1.86 \mathrm{~Sv}$ and its minimum in March 2011 (weak La Nina) of -0.06 Sv. The ITF transport during El Nino (Figure 7b) reached its maximum when the intensity was very strong, namely in May 2016 (weak El Nino) of $2.63 \mathrm{~Sv}$ while the minimum transport occurred in July 2015 and April 2016 (moderate El Nino) which was 0.99 Sv. The monthly average condition of the ITF transport in the Halmahera Sea when La Nina (Figure 8a) reached a maximum in September 2010 (strong La Nina) of $1.65 \mathrm{~Sv}$. The minimum transport occurred in March 2011 (weak La Nina) which was $0.47 \mathrm{~Sv}$, while during the El Nino event (Figure 8b) the maximum transport occurred in October 2015 (very strong El Nino) of $-1.29 \mathrm{~Sv}$ and the minimum transport occurred in July 2015 (moderate El Nino) which was $0.48 \mathrm{~Sv}$.

The annual average condition of the ITF transport in the Maluku Sea during La Nina and EI Nino showed that the average ITF transport during the La Nina period was $-0.81 \mathrm{~Sv}$ southward, while that during El Nino was 1.54 Sv northward. Oppositely, in the Halmahera Sea the annual average ITF transport during the La Nina period was $1.09 \mathrm{~Sv}$ northward, while that during the El Nino period was $-0.5 \mathrm{~Sv}$ southward. This is in difference with the research of Sudjono et al., (2004); Oktaviani (2008); Gordon et al., (2008); and Safitri et al., (2012) especially for condition in Maluku Sea where the results showed that the ITF transport during La Nina was higher than that during El Nino but in Halmahera is the same with those previous study. This is because during La Nina, the easterly wind was stronger, causing the sea level in the western Pacific Ocean to be higher (Safitiri et al., 2012) due to a shift in the warm pool from the eastern and central Pacific regions to the western Pacific region near Indonesia (Oktaviani, 2008), so the ITF transport can be strengthened.

In addition, the ITF transport also moved northward in the Maluku Sea during El Nino and in the Halmahera Sea during La Nina. This is presumably when El Nino trade winds 
Jurnal Kelautan, 14(3), 243-253 (2021)

weakened and pushed water masses from the western Pacific Ocean to the eastern Pacific Ocean which caused the sea level in the western Pacific Ocean to decrease and a difference in height between the western Pacific Ocean and the Indian Ocean, making the ITF moves northward in Maluku Sea. The northward movement of transport in the Halmahera Sea during La Nina is caused by the NEC current strengthens and there is a strengthening of the bifurcation to the north around Halmahera waters (Wang et al., 2019). In addition, during La Nina, stronger easterly wind conditions can affect the movement of water masses in the sea, considering according to Aziz (2006), winds can affect currents to the seabed, where these easterly winds push water masses towards the western Pacific Ocean, so there is an ITF flowing northward.

\section{CONCLUSION AND RECOMENDATION}

There was no difference between the current direction in the Halmahera Sea at a depth of $155 \mathrm{~m}$ and $266 \mathrm{~m}$ during El Nino and La Nina, but the current speed during La Nina was higher than that during El Nino. There were differences in the current direction when El Nino and La Nina occurred in the Maluku Sea both at a depth of $155 \mathrm{~m}$ and at a depth of $266 \mathrm{~m}$. Especially at a depth of $266 \mathrm{~m}$, the current direction was reversed, i.e., the direction was southward during La Nina, but northward during El Nino. The current speed in the Maluku Sea was higher during La Nina than EI Nino at both depths, where the high current speed was capable to form eddy patterns. The ITF transport conditions in the Maluku and Halmahera Sea had an opposite value both during La Nina and El Nino. In addition, the direction of the ITF transport had an inverse pattern between the 2010-2011 La Nina and 2015-2016 El Nino periods.

\section{ACKNOWLEDGMENTS}

We would like to thank Copernicus Marine and Ggweather for providing free access to data that can be used in this research. We would also like to thank the Indonesian School of Meteorology, Climatology and Geophysics (STMKG) for funding the publication of this research.

\section{REFERENCES}

Arief, D., \& S. P. Murray. (1996). LowFrequency Fluctuations in the Indonesian Throughflow trough Lombok Strait, Journal of Geophysical Research, 101(C5), 12455-12464.

Atmadipoera, A. S., \& Mubaraq, G. L. (2016).
Structure and Variability of Indonesian

Througflow at Sulawesi Sea. Jurnal Kelautan Nasional, 11(3), 159-174.

Atmadipoera, A. S., Horhoruw, S. M., Purba, M. \& Nugroho, D. Y. (2016). Spatial and Temporal Variation of Indonesian Throughflow in the Makassar Strait. Jurnal IImu dan Teknologi Kelautan Tropis, 8(1), 299-320.

Atmadipoera, A. S., Jasmine, A. S., Purba, M., \& Kuswardani, A. R. T. D. (2020). Upwelling Scharacteristics in the Southern Java Waters during Strong La Nina 2010 and Super El Nino 2015. Jurnal IImu dan Teknologi Kelautan Tropis, 12(1), $257-276$.

Aziz, M. F. (2006). Gerak Air di Laut, Oseana, 31(4), 9-21.

Cresswell, G., Frische, A., Peterson, J., \& Quadfasel, D. (1993). Circulation in the Timor Sea. Journal of Geophysical Research, 98(C8), 14.379-14.389

Fieux, M., Molcard, R., \& llahude, A. G. (1996). Geostrophic Transport of the PacificIndian Oceans Throughflow. Journal of Geophysical Research, 101(C5), 1242112432.

Ggweather. (2019). El Nino and La Nina Years and Intensities, https://ggweather.com/enso/oni.htm, accessed on 24 December 2019 and 13 January 2020.

Gordon, A. L. \& Fine, R. A. (1996). Pathways of Water between the Pacific and Indian Oceans in the Indonesian Seas. Nature, 379, 146-149.

Gordon, A. L. (2005). Oceanography of the Indonesian Seas and Their Throughflow. Oceanography, 18(4), 14-27.

Gordon, A. L., Susanto, R. D., Ffield, A., Huber, B. A., Pranowo, W., \& Wirasantosa, S. (2008). Makassar Strait Troughflow 2004 to 2006. Geophysical Research Letters, 35(L24605), 1-5.

Gordon, A. L., Susanto, R. D., \& Ffield, A. (1999). Throughflow within Makassar Strait. Geophysical Research Letters, 26(21), 3325-3328.

Hasanudin, M. (1998). Arus Lintas Indonesia (ITF). Oseana, 23(2), 1-9.

Luick, J. L. (2001). Current Measurements in the Maluku Sea. Journal of Geophysical Research, 106(C7), 13.953-13.958.

Meyers, G. (1996). Variation of Indonesian Throughflow and the El Nino Southern Oscillation. Journal of Geophysical Research, 101(C5), 12255-12263.

Molcard, R., Fieux, M., \& llahude, A. G. (1996). The Indo-Pacific Throughflow in the Timor Passage. Journal of Geophysical 
Rejeki et al., Variations Of Indonesian Throughtflow Transport

Research, 101(C5), 12.411-12.420.

Molcard, R., Fieux, M., \& Syamsudin, F. (2001). The Troughflow within Ombai Strait. Deep-Sea Research I, 48, 1237-1253.

Molcard, R., Fieux, M., Swallow, J. C., llahude, A. G., \& Banjarnahor, J. (1994). Low Frequency Variability of the Currents in Indonesian Cahnnels (Savu-Roti and Roti-Ashmore Reef). Deep-Sea Research I, 41(11/12), 1643-1661.

Murray, S. P., \& Arief, D. (1988). Throughflow into the Indian Ocean through the Lombok Strait January 1985-January 1986. Nature, 333, 444-447.

Nanlohy, P., Nusaly, M., Eleewujaan, A. A., Luturmas, R. W., Latue, A. P., Supusepa, F., Lokollo, R., Andayani, H., \& Elim, H. I. (2018). Variabilitas transport Volume Massa Air di Laut Banda Bagian Barat. Journal of Multidisciplanry Application on Philosophy and Science (JAMFAS), 1(1), 23-29.

Oktaviani, A. P. P., Ningsih, N. S., Brodjonegoro, I. S., \& Tisiana, A. R. T. D. (2008). Analisis Sinyal El Nino Southern Oscillation (ENSO) dan Hubungannya dengan Variabilitas Arus Lintas Indonesia di Selat Lifamatola. IImu Kelautan, 13(4), $209-218$.

Safitri, M., Cahyarini, S. Y., \& Putri, M. R. (2012). Indonesian Throughflow Transport Variations and Oceanographic's Parameter in Timor Seas as an Indication of ENSO Events. Jurnal IImu dan Teknologi Kelautan Tropis, 4(2), 369-377.

Sprintall, J., Wijffels, S. E., Molcard, R., \& Jaya, I. (2009). Direct Estimate of the Indonesian Througflow Entering the Indian Ocean: 2004-2005. Journal of Geophysical Research, 114(C07001), 119.

Sudjono, E. H., Mihardja, D. K., \& Ningsih, N. S. (2004). Indikasi Fluktuasi Arus Lintas Indonesia di Sekitar Selat Makassar Berdasarkan Model Numerik. Jurnal Geologi Kelautan, 2(1), 29-35.

Susanto, R. D., \& Gordon, A. L. (2005). Velocity and Transport of the Makassar Strait Troughflow. Journal of Geophysical Research, 110(C01005), 1-10.

Tranchant, B., Reffray, G., Greiner, E., Nugroho, D., Koch-Larrouy, A., \& Gaspar, P. (2016). Evaluation of an Oerational Ocean Model Configuration at $1 / 12^{\circ}$ Spatial Resolution for the Indonesian Seas (NEMO2.3/INDO12)Part 1: Ocean Physics. Geoscientific Model Development, 9, 1037-1064.

Wang, L., Zhou, L., Xie, L., Zheng, Q., Li, Q., \&
Li, M. (2019). Seasonal and Interannual Variability of Water Mass Sources of Indonesia Throughflow in the Maluku Sea and the Halmahera Sea. Acta Oceanologica Sinica, 38(4), 58-71.

Wattimena, M. C., Atmadipoera, A. S., Purba, M., Nurjaya, I. W., \& Syamsudin, F. (2018). Indonesian Throughflow (ITF) Variability in Halmahera Sea and Coherency with New Guinea Coastal Current. IOP Conference Series: Earth and Environmental Science, 176(1), 115.

Wyrtki, K. (1987). Indonesian Through Flow and the Associated Pressure Gradient. Journal of Geophysical Research, 92(C12), 12.941-12.946

Yuan, D., Li, X., Wang, Z., Li, Y., Wang, J., Yang, Y., Hu, X., Tan, S., Zhou, H., Wardana, A. K., Surinati, D., Purwandana, A., Ismail, M. F. A., Avianto, P., Dirhamsyah, D., Arifin, Z., \& Storch, J. S. V. (2018). Observed Transport Variations in the Maluku Channel of the Indonesian Seas Associated with Western Boundary Current Changes. Journal of Physical Oceanography, 48, 1803-1813. 